\title{
Interstitial deletion of the short arm of chromosome 5 in a mother and three children
}

\author{
J L WALKER*, C E BLANK*, AND B A M SMITH† \\ ${ }^{*}$ Centre for Human Genetics, 117 Manchester Road, and $\dagger$ The Northern General Hospital, Sheffield.
}

SUMMARY An interstitial deletion (5) $(\mathrm{p} 13 \mathrm{p} 15 \cdot 1)$ was found in a mentally retarded woman and three of her four children. The variable manifestation of this chromosomal defect and the relevance of this particular deletion to the cri du chat syndrome are discussed. To our knowledge the only other reported case of inherited $5 p$ deletion from an affected parent involved the terminal segment of the 5 p $15 \cdot 3$ band. ${ }^{1}$

\section{Case report}

Chromosome analysis of amniotic fluid cells was requested because of advanced maternal age (38 years). An interstitial deletion of band p14 in the short arm of chromosome 5 was identified, suggesting a possible clinical diagnosis of the cri du chat syndrome. The parental karyotypes showed that the mother had the same chromosome abnormality as the fetus: $\operatorname{del}(5)($ pter $\rightarrow$ p15 $1::$ p13 $\rightarrow$ qter $)$. This deletion was also identified in two of her children (fig 1). The father's karyotype was normal. The mother and the two chromosomally abnormal children showed dysmorphic features and moderate mental retardation. Termination of pregnancy was declined and the child was born in June 1982. The karyotype of the fetus was confirmed after birth. No other family members were available for investigation.

\section{Clinical features}

The mother (fig 2, table) has a long face and marked microcephaly. She had attended a school for the educationally subnormal (ESN(M)) but remained illiterate. The eldest (II.1) has an unremarkable face, is of short stature, and has a normal head circumference. He attends a school for the educationally subnormal (ESN(M)). II.3 is also short, has a normal head size but, unlike her brother, she has dysmorphic facial features (fig 2, table) which are

Received for publication 20 March 1984 Accepted for publication 8 May 1984. often seen in the cri du chat syndrome. At 7 weeks of age II.4 has no dysmorphic features nor microcephaly. She is, however, very short. The head circumference, although small for her age, is proportionate to her stature. Her cry is normal. No

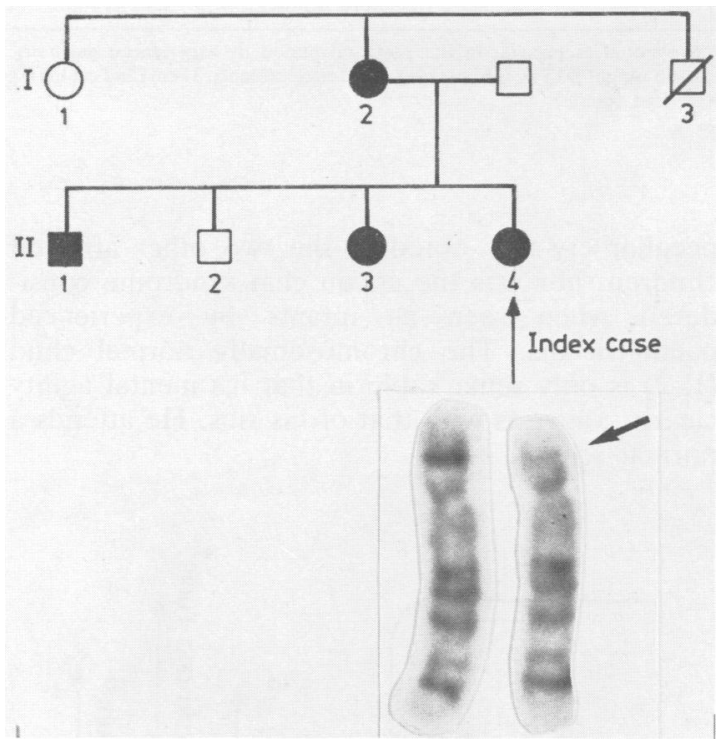

FIG 1 Family pedigree.

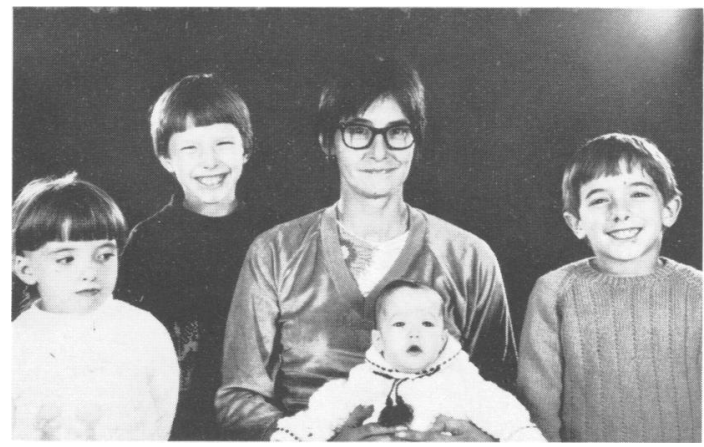

FIG 2 Mother and children. From left to right II.3, II.1, I.2, II.4, and II.2. 
TABLE Main features of clinical interest.

\begin{tabular}{|c|c|c|c|c|c|c|}
\hline & Age & $\begin{array}{l}\text { Height } \\
(\mathrm{cm})\end{array}$ & $\begin{array}{l}\text { Head circumference } \\
(\mathrm{cm})\end{array}$ & Facial dysmorphism & $\begin{array}{l}\text { Marked } \\
\text { development }\end{array}$ & Cry \\
\hline I. 2 & Adult & $\begin{array}{l}158 \\
\text { ( } 25 \text { th centile) }\end{array}$ & $\begin{array}{l}51 \cdot 5 \\
\text { (less than 2nd centile) }\end{array}$ & A 'long' face & $\mathrm{ESN}(\mathrm{M})$ & $\begin{array}{l}\text { Not } \\
\text { peculiar }\end{array}$ \\
\hline II. 1 & $8 \mathrm{y}$ & $\begin{array}{l}120 \\
(10 \text { th to } 25 \text { th } \\
\text { centile) }\end{array}$ & $\begin{array}{l}51 \cdot 5 \\
\text { (50th centile) }\end{array}$ & $\begin{array}{l}\text { Forward slanting upper } \\
\text { incisors. Irregular teeth }\end{array}$ & $\operatorname{ESN}(M)$ & $\begin{array}{l}\text { Not } \\
\text { peculiar* }\end{array}$ \\
\hline II. 2 & $61 / 2$ y & $\begin{array}{l}115 \\
\text { ( } 25 \text { th to } 50 \text { th } \\
\text { centile) }\end{array}$ & $\begin{array}{l}52 \cdot 5 \\
(75 \text { th centile })\end{array}$ & None & Normal & - \\
\hline II. 3 & $4^{1 / 2}$ y & $\begin{array}{l}100 \\
\text { (10th to } 25 \text { th } \\
\text { centile) }\end{array}$ & $\begin{array}{l}49 \cdot 5 \\
(25 \text { th centile })\end{array}$ & $\begin{array}{l}\text { Epicanthic folds. } \\
\text { Moderately wide set eyes. } \\
\text { Irregular teeth. Thickened } \\
\text { helixes }\end{array}$ & $\operatorname{ESN}(M)$ & $\begin{array}{l}\text { Not } \\
\text { peculiar* }\end{array}$ \\
\hline II. 4 & $7 \mathbf{w k}^{\dagger}$ & $\begin{array}{l}50 \\
\text { (3rd centile) }\end{array}$ & $\begin{array}{l}36 \\
\text { (3rd centile) }\end{array}$ & None & - & $\begin{array}{l}\text { Not } \\
\text { peculiar }\end{array}$ \\
\hline
\end{tabular}

${ }^{*}$ Not noted as peculiar in the postnatal period by experienced paediatrician. $\dagger$ Birth weight $2.15 \mathrm{~kg}$ ( 3 rd centile); head circumference $31 \mathrm{~cm}$ ( 2 nd centile); gestation 37 weeks. At $11 \mathrm{months}$ : height $68 \mathrm{~cm}$ ( $3 \mathrm{rd}$ centile); head circumference 43 (2nd centile).

peculiar cry was noted in the two other affected children, nor was the cri du chat syndrome considered when seen as infants by experienced paediatricians. The chromosomally normal child (II.2) is only remarkable in that his mental agility clearly contrasts with that of his sibs. He attends a normal school.

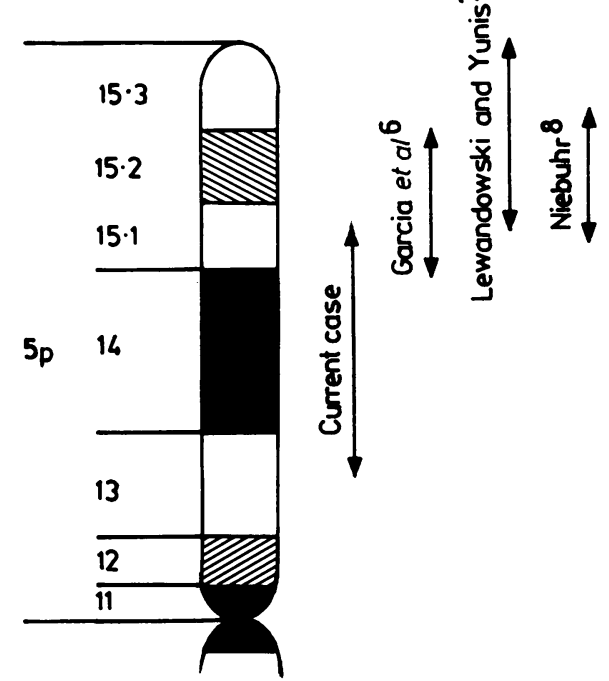

FIG 3 Deletion in this case compared with suggested localisations of the critical region in the cri du chat syndrome.

\section{Discussion}

It is interesting to note that an apparently identic $\mathbb{B}$ chromosome abnormality has variable manifesta tion. The single consistent feature is moderate mental subnormality. Only one member (II.3) has significantly dysmorphic face. The others are of short stature which is very marked in II.4. Significant microcephaly is present only in the mother (I.2).

Partial deletion of the short arm of chromosome 5 is usually associated with the cri du chat syndrome. ${ }^{2} 3$ The 'characteristic' clinical features of this syndrome are especially obvious in the newborn. ${ }^{34}$ The distinctive mewing cry becomies less striking after the first year although an abnormal cry may be noted even in adult life. The facial features suggestive of this clinical diagnosis become less obvious in late childhood. ${ }^{35}$ In the neonate, the characteristic cry, the striking craniofacial dysmorphism, and low birth weight allow a confident diagnosis of the cri du chat syndrome. ${ }^{3}$ II. 4 had a low birth weight (3rd centile) but did not have an odd cry and the facies was unremarkable. Crownheel length, not severely impaired in the cri du chat syndrome, was markedly abnormal (3rd centile). A diagnosis of cri du chat syndrome would not have been considered had the karyotype not already been known. No history of a peculiar cry and only moderate subnormality in the other affected family members are also against a diagnosis of this syndrome. Furthermore, significant microcephaly, a feature present in most persons with cri du chat 
syndrome, was observed in the mother alone. Only one member (II.3) had obvious facial dysmorphism which is compatible with, but not specific for, the cri du chat syndrome. In at least three reports ${ }^{6-8}$ attempts were made to locate the 'critical' region in the cri du chat syndrome. They are compared in fig 3 with the deletion of band $5 \mathrm{p} 14$ observed in our family. The authors of these reports analysed over 40 cases with acceptable features of cri du chat syndrome, and located the phenotypically relevant site as distal to the deletion we report, although there could be a marginal overlap with our case. This may explain the minimal features of cri du chat syndrome noted in our family. However, the lack of consistency in the clinical features observed remains unexplained.

\footnotetext{
References

1 Baccichetti C. Del (5p) without "cri du chat" phenotype. Hum Genet 1982;60:389.
}

${ }^{2}$ Lejeune J, Lafourcade J, Berger R, et al. Trois cas de deletion partielle du bras court d'un chromosome 5. C R Acad Sci [D] (Paris) 1963;257:3098-102.

${ }^{3}$ Niebuhr E. The cri du chat syndrome. Epidemiology, cytogenetics and clinical features. Hum Genet 1978;44:227-75.

${ }^{4}$ Gordon RR, Cooke P. Facial appearance in cri du chat syndrome. Dev Med Child Neurol 1968;10:69-76.

5 Breg WR, Steele MW, Miller OJ, Warburton D, de Capoa A. The cri du chat syndrome in adolescents and adults: clinical findings in 13 older patients with partial deletion of the short arm of chromosome No 5 (5p-). J Pediatr 1970;77:782-91.

${ }^{6}$ Garcia FP, Garrabou LB, Mezquita GA, Garcia VA, Garcia MLM. Chromosome deletion point in cri du chat syndrome. An Esp Pediatr 1976;9:170-3.

${ }^{7}$ Lewandowski RC, Yunis JJ. Phenotypic mapping in man. In: Yunis JJ, ed. New chromosomal syndromes. New York: Academic Press, 1977:369-94.

${ }^{8}$ Niebuhr E. Cytological observations in 35 individuals with a 5p- karyotype. Hum Genet 1978;42:143-56.

Correspondence and requests for reprints to Ms J L Walker, Centre for Human Genetics, 117 Manchester Road, Sheffield S10 5DN.

\title{
A live infant with trisomy 14 mosaicism and nuclear abnormalities of the neutrophils
}

\author{
B DALlaPicCOLA*, G FERRANTI*, A GiAnNOTTI†, G NOVELLI*, \\ L PASQUINI†, AND B PORFIRIO*
}

${ }^{*}$ Department of Human Genetics, University of Urbino; and †Bambin Gesù Hospital, Rome, Italy.

SUMmaRY Mosaic trisomy 14 is described in a patient with severe developmental retardation and congenital malformations. Together with a few previous reports, this case suggests the existence of a syndrome associated with this chromosome imbalance. Hitherto unrecognised manifestations of trisomy 14 mosaicism were, in our patient, abnormalities of the neutrophil nuclei, which consisted of multiple pedunculated or sessile projections, similar to those characteristically associated with trisomy 13 syndrome.

Trisomy 14 accounts for less than $1 \%$ of chromosomal aberrations observed in spontaneous abortions. ${ }^{1}$ The lethality of this aneuploidy is attested by its almost complete absence among liveborn infants and by the observation that trisomy 14 mosaicism was invariably present in the few living subjects with this imbalance. ${ }^{2-7}$

Received for publication 10 April 1984.

Accepted for publication 11 April 1984
We describe a new case of trisomy 14 mosaicism that supports the existence of a characteristic clinical condition associated with this aneuploidy and suggests that nuclear abnormalities of the neutrophils could be an additional feature of the syndrome.

\section{Case report}

The proband was born in 1983 after a 40 week pregnancy complicated by threatened abortion during the second month and by polyhydramnios. He was the only child of healthy, unrelated parents. At birth the mother was 33 years old and the father 32 . Birth weight was $2400 \mathrm{~g}$ ( $<3$ rd centile; 50th centile for 34 weeks) and length $48 \mathrm{~cm}$ (3rd to 10th centile). At 24 hours the patient had a seizure. During the first months he stayed in hospital because of feeding difficulties and delayed growth resulting from bilateral cleft lip and palate and a congenital heart defect (tetralogy of Fallot), which was operated on at 3 months of age.

He was seen by us at 6 months (fig 1). At that time his weight was $3800 \mathrm{~g}(<3 \mathrm{rd}$ centile; 50th centile for 3 weeks), length $52 \mathrm{~cm}(<3 \mathrm{rd}$ centile; 50 th centile 